\title{
O EMBRIÃO HUMANO: SUA PERSONALIDADE E A EMBRIOTERAPIA
}

\section{Elimar Szaniawski"}

RESUMO: O presente artigo analisa a situação jurídica do embrião excedente, sustentando que o direito à vida e de nascer, a partir da Constituição da República de 1988 é direito limitado. A Teoria da Realidade Técnica atribui à técnica jurídica o momento da fixação da aquisição da personalidade do ser humano. Sustenta-se a constitucionalidade do artigo 5. ${ }^{\circ}$, da Lei de Biosegurança, não estando vedado ao legislador infraconstitucional a imposição de limites ao direito à vida e de nascer dos embriões excedentários in vitro.

\section{INTRODUÇÃO}

Em 2001, tivemos a oportunidade de trazer a lume algumas considerações sobre a polêmica dos embriões excedentes e o destino a ser dado aos mesmos, em trabalho de nossa autoria, intitulado "O Embrião excedente - E o primado do Direito à vida e de nascer". ${ }^{1}$

\footnotetext{
* Advogado. Mestre e Doutor em Direito pela Universidade Federal do Paraná. Professor Adjunto de Direito Civil na Universidade Federal do Paraná. Membro do Instituto de Direito Comparado Luso Brasileiro e do Instituto dos Advogados do Paraná.

${ }^{1}$ Trabalho publicado na RTDC. Vol. n. ${ }^{\circ} 8$, ps. 83/107. 2001
}

RÉSUMÉ: This article analyses the juridical situation of the exceeding foetus, claiming that the right to life and birth is limited by the Brazilian Constitution. According to the Theory Technical Reality, it is the juridical technique that establishes when human beings acquire personality. The constitutionality of Article 5 of the Bio Security Law is maintained, and the legislator is allowed to outline the limits of the in vitro exceeding foetuses' right to life and birth.

Optamos, em razão de coerência com nosso pensamento, em afirmar ser o embrião, mesmo, aquele criado in vitro, portador de personalidade natural, tal qual a possui o embrião que se desenvolve no interior do ventre materno.

Opusemo-nos à corrente de pensamento que defende o simples descarte dos embriões produzidos in vitro, não utilizados na reprodução assistida, bem como não nos entusiasma a idéia da utilização dos mesmos pelas técnicas da embrioterapia, que procura curar determinadas moléstias a partir da utilização das células-tronco retiradas do embrião. Tal falta de entusiasmo com as 
técnicas da embrioterapia tem origem em dois pontos.

O primeiro, pelo fato de a utilização das células-tronco retiradas do embrião, o levarem a morte, preferindo outras técnicas terapêuticas como, por exemplo, a terapia de restauração neurológica que possui idêntica eficiência. A utilização de produtos derivados da placenta humana se mostram extremamente eficazes no tratamento do Vitiligo, da Psoriasis e da Alopecia. ${ }^{2}$ A placenta humana é rica em células-tronco, que permitem a reprodução celular e a formação de tecidos semelhantes aos produzidos através das células-tronco embrionárias, sem, porém, utilizar e destruir o embrião. O cordão umbilical é, igualmente,

${ }^{2}$ O Centro de Pesquisa e Restauração Neurológica CIREN, de Havana, Cuba tem desenvolvido o tratamento da doença de Parkinson \{clínica baseada no princípio da neuro plasticidade, para lograr a recuperação estrutural e funcional do Sistema Nervoso lesionado\}, mediante atividade médica multidisciplinar, combinando terapias neurológica, psiquiátrica, cirúrgica e fisioterápica. Destaca-se, entre as diversas terapias combinadas, a terapia cirúrgica, através da qual se realiza a cauterização de ambos os lados do subtálamo, que é a parte do cérebro que controla a coordenação da maior parte dos movimentos. Esta cauterização visa queimar alguns neurotransmissores superativos que causam o tremor e a rigidez que caracteriza a doença de Parkinson. Com o auxílio de computador e de programas avançados e mediante a cooperação do próprio paciente, os médicos das especialidades, acima mencionadas, localizam e identificam os pontos exatos do subtálamo que afetam cada parte do corpo do paciente. Os resultados obtidos são na razão de uma recuperação geral do paciente em mais de $90 \%$, havendo grande expectativa da evolução para a melhoria dessas técnicas, embora seja esta terapia realizada apenas a nível experimental. (Cf. " O embrião excedente ..., p. 97).

A Retinose Pigmentaria vem sendo tratada através da combinação de técnica cirúrgica e a aplicação de ozônio. A eletroestimulação, a vitaminoterapia e a terapia com oligoelementos, detêm a progressiva perda de visão pelo paciente. Mais informações sobre as novas terapias se encontra em: http://www.infomed.sld.cu/instituciones/ htm. Acessado em 15.08.2005. rica fonte de células-tronco, cuja reprodução celular e formação de tecidos, é tão eficiente ou mais, do que os retirados do embrião. A utilização de células-tronco adultas retiradas do próprio enfermo tem demonstrado ser uma terapia mais adequada do que a utilização de células-tronco de um embrião, geneticamente estranho ao paciente.

Mediante o emprego destas novas modalidades terapêuticas, tem-se alcançado um enorme sucesso, sem necessitar sacrificar embriões humanos rejeitados pelos genitores.

O segundo ponto reside na personalidade do embrião. Sendo o embrião considerado um ser humano em desenvolvimento, uma spes personae, não pode ser simplesmente descartado ou destruído.

As legislações da atualidade têm-se filiado à teoria concepcionista da aquisição da personalidade do ser humano, rejeitando a clássica visão natalista, reminiscência do pensar do Séc. XIX, de influência do direito romano. De acordo com a teoria concepcionista, o início da personalidade do ser humano dar-se-á a partir da concepção, conseqüentemente, é o embrião humano portador de personalidade, é uma pessoa, é um sujeito de direitos, mesmo aquele que se desenvolve in vitro. Em virtude destes fatos, propusemos, em nosso trabalho, a drástica redução da produção de embriões em laboratórios e nas clínicas de fertilização e a utilização dos embriões excedentes para adoção por famílias inférteis que queiram vivenciar a maternidade e a paternidade, ao invés de descartá-los ou utilizá-los em experiências científicas.

A promulgação da Lei n. ${ }^{\circ} 11.105$ de 24.03.2005, destina-se a regulamentar os incisos II, IV e V, do $\S 1^{\circ}$, do art. 225 , da 
Constituição Federal, estabelecendo normas de segurança e mecanismos de fiscalização sobre a construção, o cultivo, a produção, a manipulação, o transporte, a transferência, a importação, a exportação, o armazenamento, a pesquisa, a comercialização, o consumo, a liberação no meio ambiente e o descarte de organismos geneticamente modificados OGM e seus derivados.

Surpreendentemente, o legislador inseriu no meio da referida lei, como se atirasse aleatoriamente uma pelota de barro à parede, um dispositivo legal que constitui o art. 5. destinado a autorizar a pesquisa, a terapia e a utilização de células-tronco embrionárias obtidas de embriões humanos produzidos mediante técnica de fertilização in vitro e não utilizados no respectivo procedimento. Soa o art. 5. ${ }^{\circ}$ da Lei n. ${ }^{\circ} 11.105 / 2005$ :

"É permitida, para fins de pesquisa e terapia, a utilização de células-tronco embrionárias obtidas de embriões humanos produzidos por fertilização in vitro e não utilizados no respectivo procedimento, atendidas as seguintes condições:

I - sejam embriões inviáveis; ou

II - sejam embriões congelados há 3 (três) anos ou mais, na data da publicação desta Lei, ou que, já congelados na data da publicação desta Lei, depois de completarem 3 (três) anos, contados a partir da data de congelamento.

$\S 1^{\circ}$ Em qualquer caso, é necessário o consentimento dos genitores.

$\S 2^{\circ}$ Instituições de pesquisa e serviços de saúde que realizem pesquisa ou terapia com células-tronco embrionárias humanas deverão submeter seus projetos à apreciação e aprovação dos respectivos comitês de ética em pesquisa.

$\S 3^{\circ}$ É vedada a comercialização do material biológico a que se refere este artigo e sua prática implica o crime tipificado no art. 15 da Lei n. ${ }^{\circ}$ 9.434, de 4 de fevereiro de 1997."
A autorização que a referida Lei traz no art. 5. $^{\circ}$, consiste na utilização de células tronco obtidas de embriões humanos produzidos por fertilização in vitro, abrindo novas discussões sobre o embrião excedente, produzido in vitro, ser possuidor ou não, de personalidade natural e, consequentemente, ser sujeito de direitos merecendo a tutela do direito à vida e de nascer.

Em virtude deste inoportuno dispositivo legal, perdido no meio da legislação que regulamenta matéria de biosegurança, uma vez que pesquisas com células-tronco mereceriam legislação própria e específica e não, somente, um único artigo inserido na Lei de Biosegurança, o Procurador Geral da República, Cláudio Fonteles, interpôs no mês de maio de 2005, perante o Supremo Tribunal Federal, ação direta de inconstitucionalidade do art. 5. ${ }^{\circ}$, da mencionada Lei n. ${ }^{\circ}$ 11.105/2005, argüindo, a partir de abalizadas opiniões de biólogos, que sustentam a idéia de que a partir da fecundação inicia-se a vida, a inconstitucionalidade do presente dispositivo infraconstitucional, diante do mandamento contido no caput do art. 5..$^{\circ}$ da Constituição, que garante amplamente o direito à vida, considerando o ser humano concebido, mesmo in vitro, uma vida humana.

Diante desta iniciativa da Procuradoria Geral da República, cabe indagar se, efetivamente, $\mathrm{o}$ art. 5. ${ }^{\circ}$, da Lei n. $.^{\circ} 11.105 / 2005$ seria inconstitucional ou se o legislador infraconstitucional estaria autorizado a legislar, impondo limites ou relativizando o direito à vida e de nascer, autorizando, desta maneira, o aproveitamento das células-tronco extraídas de embrião in vitro inviável ou congelado há três anos ou mais, consoante permissivo legal. 
O art. 5. ${ }^{\circ}$, da Lei n. ${ }^{\circ}$ 11.105/2005, tal como foi inserido na Lei de Biosegurança, nos estimulou a proceder novas reflexões, que em parte constituem-se em uma evolução do nosso pensamento manifestado anteriormente em outros trabalhos e que será trazido ao final.

Para podermos entender a extensão do problema e das conseqüências jurídicas que a admissibilidade do embrião in vitro ser portador de personalidade, será necessário trazermos algumas considerações sobre as noções de embrião excedente, de embrioterapia, bem como sobre a personalidade do ser humano e o momento de sua aquisição.

\section{DA NOÇÃO DE EMBRIÃO EXCEDENTE}

No presente capítulo, traremos uma breve noção das técnicas da reprodução humana assistida e do significado de embrião excedente.

A reprodução humana assistida é conceituada como sendo um procedimento médico destinado a possibilitar aos casais que não possam obter a fecundação da mulher por meios naturais, lograrem a fecundação por técnicas artificiais, objetivando o nascimento de filhos. ${ }^{3}$ As técnicas da reprodução humana assistida podem ser resumidas em duas modalidades. A primeira, consiste da introdução do sêmen do homem na genitália interna da mulher por meios artificiais. Esta técnica é denominada inseminação artificial, conhecida pela sigla (IA). A segunda modalidade de fecundação

${ }^{3}$ SZANIAWSKI, Elimar. O embrião excedente o primado do direito à vida e de nascer, p. 83. artificial é a fertilização in vitro denominada pela sigla (FIV). A fecundação in vitro realiza-se mediante reunião do sêmen e do óvulo em uma proveta, artificialmente provocada, resultando na fecundação do óvulo. Iniciado o desenvolvimento do zigoto e a formação de embriões, serão estes, posteriormente, introduzidos no útero da mulher para a gestação. ${ }^{4}$

As técnicas de reprodução assistida exigem, para o sucesso da fertilização, o emprego de diversos embriões para cada tentativa de inseminação. Por essa razão, o médico deverá estimular a produção de óvulos, mediante aplicação diária de injeções de hormônios na mulher, durante o período de dez dias. Os hormônios provocarão o aumento da ovulação de apenas um por mês, para a produção de até quinze óvulos no mesmo período. O procedimento de fertilização inicia a partir da retirada dos óvulos do ovário sendo armazenados em uma estufa própria. Em geral, cada óvulo deverá receber um espermatozóide para fecundálo, que será introduzido na célula germinal feminina por meio de uma microagulha. Dos quinze óvulos fertilizados, cerca de dez se desenvolvem constituindo embriões. Iniciada a reprodução celular os embriões serão inseminados no útero da mãe. A boa técnica recomenda a transferência de dois a três embriões para o útero da mulher em cada tentativa de gestação, sendo os demais congelados em nitrogênio líquido, permanecendo em depósito à espera de um destino. Estes embriões podem, segundo esta técnica, ser mantidos vivos e congelados

\footnotetext{
4 SZANIAWSKI, Elimar. Ult. ob. cit., p. 87.
} 
indefinidamente, mesmo fora do organismo de uma mulher. ${ }^{5}$ Deste modo, encontram-se criopreservados em bancos de depósito de material genético e nas clínicas de fertilização assistida espalhadas pelo mundo, milhões de embriões que não foram utilizados para gestação, constituindo-se nos chamados embriões excedentes.

A popularização das técnicas de reprodução assistida, desenvolvida em larga escala nos últimos anos em todo o mundo, provocou um grande problema que consiste no destino a ser dado aos milhões de embriões produzidos nas clínicas de fertilização humana mas que não serão aproveitados para a gestação e a maternidade das pacientes, pelo fato de as mesmas, terem alcançado a maternidade desejada nas tentativas de inseminação anteriormente realizadas.

Diante deste lastimável quadro, que revela a existência de milhões de embriões congelados e depositados em clínicas de fertilização humana, surge a grande indagação: O que fazer com todos estes embriões que não serão utilizados para a reprodução humana?

Uma das propostas de destino dos embriões que não serão utilizados para a gestação da futura mãe, que vem despertando um enorme interesse na comunidade científica, diz respeito à doação dos embriões excedentes para experiências biomédicas e na utilização das células embrionárias tronco no tratamento de inúmeras moléstias, muitas consideradas incuráveis pela medicina tradicional, por meio de um novo e revolucionário sistema de tratamento denominado embrioterapia.

5 MEIRELLES, Jussara Maria Leal de. A Vida humana Embrionária e sua Proteção Jurídica. Rio de Janeiro: Renovar, 2000. p. 22-23.
A embrioterapia consiste na parte da Medicina que se dedica ao estudo, às pesquisas e na possível aplicação de uma nova modalidade de tratamento de determinadas doenças graves, na qual são utilizadas células-tronco e para a fabricação de medicamentos capazes de curar diversas doenças, em especial, as hematológicas, as oncológicas e as onco-hematológicas. Existem diferentes pesquisas em andamento, dedicadas ao tratamento de doenças degenerativas como o Mal de Alzheimer, o Mal de Parkinson, a Esclerose Múltipla, o derrame cerebral, o diabetes e os vários distúrbios cardiovasculares, em que vem sendo testada a embrioterapia, prometendo, esta, bastante sucesso na recuperação dos pacientes. ${ }^{6}$ Assim, em diversas partes do mundo, vêm sendo desenvolvidos estudos de novas terapias a partir de células-tronco, objetivando o tratamento da paralisia dos membros superiores, o desenvolvimento de tecidos musculares, nervosos, pancreáticos, hepáticos e cartilagens, buscando as pesquisas a cura do câncer de pulmão, dos rins, da medula óssea, da Doença de Chagas, na recuperação de queimados e, também, na cura da AIDS. ${ }^{7}$

Uma das técnicas mais empregadas na terapia mediante células-tronco, consiste na extração das referidas células do embrião desenvolvendo-as em um meio adequado para tal. Estas células são inseridas em uma proveta para permitir seu desenvolvimento, obtendo-se, desta maneira, diversas células-tipo que,

${ }^{6}$ SZANIAWSKI, Elimar. $O$ embrião excedente ..., p. 92 .

${ }^{7}$ SZANIAWSKI, Elimar. $O$ embrião excedente ..., p. $92-93$. 
posteriormente, ao se desenvolverem, poderão constituir as células sangüíneas, as células nervosas, as células medulares e ósseas, as células cardíacas, as células do fígado, as células epidérmicas etc. Dependendo da modalidade da enfermidade e do órgão atingido, deverá ser escolhida a célula-tipo correspondente a ser injetada no corpo do paciente. O desenvolvimento da célula-tipo adequada no corpo humano, reparará o órgão enfermo, obtendo a cura do mesmo. As células-tronco extraídas do embrião possuem o potencial de se transformarem em qualquer tipo de tecido desejado pelo pesquisador como, por exemplo, em células do músculo cardíaco, que regenerará as artérias e as áreas lesadas por infartos. Outro exemplo nos mostra que as células-tronco que são inseridas no cérebro humano têm a possibilidade de se desenvolver em células cerebrais, vindo a cumprir as tarefas dos neurônios lesados, atuando na recuperação das vítimas das moléstias e lesões cerebrais.

Diante de todo este potencial de cura de doenças e da recuperação de órgãos lesionados, nas mais diversas partes mundo estão sendo desenvolvidos projetos dedicados à pesquisas da embrioterapia, que propõe a utilização de células-tronco extraídas de embriões e no desenvolvimento de terapias e medicamentos capazes de curar, definitivamente, uma série de doenças que nos afligem na atualidade.

O recente sucesso das pesquisas realizadas e os resultados obtidos que prometem a cura da grande maioria das moléstias que nos acometem hodiernamente, têm provocado uma grande euforia entre médicos e pacientes que buscam a cura de seus males.
Embora em que pese o inestimável valor de cura desta nova modalidade terapêutica, existe forte oposição em relação à adoção desta modalidade de tratamento das doenças humanas, pelo fato de que a extração da célulatronco do embrião provoca sua destruição.

A principal corrente de pensadores que se opõem ao emprego de célulastronco extraídas de embriões no tratamento das moléstias humanas, fundamenta sua oposição alegando que a morte do embrião constitui-se na morte de um ser humano, no assassinato de uma pessoa que está viva e em desenvolvimento e que possui o direito à vida e de nascer.

Portanto, negam esses pensadores aos profissionais da saúde, aos laboratórios e às instituições farmacêuticas, o direito de sacrificar uma vida humana em estado embrionário para salvar a vida de outra pessoa que já nasceu e exerceu seu direito à vida e de nascer. Para esta corrente, que entende que a partir da concepção é criado um novo ser humano, o embrião será sempre, em qualquer fase do desenvolvimento, considerado uma pessoa humana, cuja vida não poderá ser sacrificada para salvar outra. Vislumbram estes pensadores uma colisão de direitos fundamentais entre o direito à vida e de nascer do embrião, futuro ser humano que ora se desenvolve $\mathrm{e} o$ direito à vida e à qualidade de vida do paciente. ${ }^{8}$

Essa corrente de pensamento não se opõe, todavia, ao emprego de células-tronco no tratamento das diversas moléstias que acometem a humanidade. Prefere, porém,

${ }^{8}$ Sobre o tema do direito à vida e o direito à qualidade de vida, consultar: SZANIAWSKI, Elimar. Direitos de personalidade ..., p.146-157. 
as técnicas que retiram as células-tronco do cordão umbilical dos recém-nascidos, da placenta humana ou, mesmo, a utilização de células tronco adultas, retiradas do próprio paciente, cuja maior vantagem seria a inexistência de eventual rejeição.

Os defensores do emprego de células embrionárias para pesquisas, para a utilização de células-tronco na embrioterapia e, inclusive, para a fabricação de medicamentos e cosméticos, consideram o embrião um mero produto de concepção, um aglomerado de células germinativas dos genitores, não se constituindo em uma spes personae, não sendo, conseqüentemente, o embrião, portador de personalidade. Assim, o embrião seria uma mera "coisa", no sentido jurídico do termo, objeto de propriedade dos doadores do sêmen e do óvulo utilizados na fecundação. O embrião, sob este aspecto, se sujeitaria às regras do direito de propriedade de coisa móvel, podendo seus proprietários dispor dele, conforme sua vontade, doando-o para a realização de experiências científicas ou, mesmo, autorizando sua destruição. De acordo com este pensamento, não ocorreria, na prática, nenhum conflito nem colisão de direitos entre o direito à vida e à qualidade de vida do paciente e o direito à vida e de nascer do embrião, uma vez que, sendo o concebido uma simples coisa, objeto de direito de propriedade de seus genitores, não possuiria direito algum.

Diante das radicais posturas assumidas pelo pensamento atual, sobre a aquisição da personalidade do ser humano, será necessária a análise da situação jurídica do embrião no âmbito do direito brasileiro, sem, no entanto, deixar de examinar o panorama da embrioterapia no direito comparado.

\section{DA EMBRIOTERAPIA E A LEI QUE A REGULAMENTA}

Consoante se verifica, o legislador brasileiro inseriu apressadamente, sem nenhum critério científico nem lógico, um dispositivo legal tratando sobre pesquisas em células-tronco extraídas de embriões humanos, no meio de uma lei que trata da regulamentação de matéria referente à biosegurança, (Lei n. ${ }^{\circ}$ 11.105/2005), que é totalmente estranha ao tema da embrioterapia humana e suas técnicas. Tal regra, posta pelo legislador, avessa à boa técnica legislativa, causa perplexidade.

A legislação brasileira admite pesquisas científicas destinadas a desenvolver terapias, mediante a utilização de células-tronco embrionárias a partir de embriões humanos produzidos in vitro e que não venham a ser utilizados em procedimentos de reprodução humana e que atendam aos seguintes pressupostos: a) que sejam embriões inviáveis; ou b) que sejam embriões crioarmazenados há mais de 3 anos da data da publicação da Lei n. ${ }^{\circ} 11.105 / 2005$ ou que, já criopreservados na data da publicação da presente norma, tenham completado três anos a partir da data do congelamento.

Da análise do texto legal se extrai que, somente, serão aproveitados para pesquisas e na embrioterapia células-tronco extraídas de embriões produzidos in vitro, que sejam diagnosticados como embriões inviáveis ou que sejam embriões antigos, congelados há mais de três anos.

Inicialmente, faz-se mister entendermos o que venha a ser um embrião inviável. Embrião inviável seria, somente, aquele que não foi aproveitado na reprodução por seus 
genitores ? E a fim de não ser simplesmente descartado, poderá ser utilizado em pesquisas ou em terapia embrionária? Ou embrião inviável significa embrião que não possui condições necessárias de desenvolvimento para resultar em uma criança saudável ? $\mathrm{Ou}$, em outras palavras, tratar-se-ia de um embrião defeituoso que se desenvolveria em uma criança com sérias deficiências físicas e psíquicas ou genéticas?

Segundo o "Pequeno Dicionário Brasileiro da Língua Portuguesa", ${ }^{9}$ a palavra inviável significa: aquilo "que não é viável." E a expressão viável quer dizer: "vivedouro; duradouro; exeqüível."

Logo, concluímos que o art. 5. ${ }^{\circ}$, da Lei n. ${ }^{\circ} 11.105 / 2005$, autoriza a realização de pesquisas com células-tronco extraídas de embriões que não possuem viabilidade, cujos resultados finais serão inexeqüíveis na prática.

Para se conhecer da viabilidade ou não, do desenvolvimento saudável de um embrião, deve-se recorrer, pelo menos, ao diagnóstico genético. Embora a ciência, de um modo geral, ainda considere o diagnóstico genético pré-implantação uterina, um procedimento experimental, não se pode afastar a certeza de que, o mesmo, consiste em uma imprescindível modalidade de terapêutica genética, destinada à realização do procedimento de inseminação com larga margem segurança para o desenvolvimento saudável da futura criança. ${ }^{10} \mathrm{O}$ diagnóstico

${ }^{9}$ FERREIRA, Aurélio Buarque de Hollanda. Pequeno Dicionário Brasileiro da Língua Portuguesa. Verbetes: inviável e viável.

${ }^{10}$ PEDROSA NETO, Antônio Henrique e FRANCO JÚNIOR, José Gonçalves. Reprodução Assistida. Iniciação à Bioética, p. 121. genético, realizado durante a fase embrionária in vitro, permite identificar possíveis alterações cromossômicas nos embriões antes de serem transferidos para o útero da mulher. ${ }^{11}$

A Resolução do CFM n. ${ }^{\circ}$ 1.358/92, que regula que as técnicas de RA dispõem nas alíneas 1 e 2, do item VI, sobre diagnóstico e tratamento de pré-embriões, determinando que toda a intervenção sobre pré-embriões in vitro, objetivando diagnósticos, não poderá ter outra finalidade se não a de avaliação de sua viabilidade ou para a detecção de doenças hereditárias, mediante obrigatório consentimento informado dos genitores. O diagnóstico genético do pré-embrião tem por principal utilidade tratar de eventual doença hereditária ou genética, de que o embrião possa ser acometido ou de impedir sua transmissão, com garantias reais de sucesso de seu desenvolvimento sadio.

No entanto, a prática não tem se mostrado tão simplista assim.

Consoante pode ser inferido pelo acima exposto, o primeiro pressuposto na obtenção de células-tronco embrionárias, exigido pelo art. 5. ${ }^{\circ}$, da Lei n. ${ }^{\circ} 11.105 / 2005$, parte da obtenção de células-tronco de embriões inviáveis congelados, possíveis portadores de doenças hereditárias ou genéticas, inviáveis, repita-se, para o desenvolvimento de uma criança saudável. Até o presente momento, a ciência desconhece a exata dimensão das conseqüências que o desenvolvimento de tecidos para pacientes sujeitos à embrioterapia poderão sofrer se submetidos à terapia com células-tronco que contenham doenças hereditárias ou genéticas.

${ }^{11}$ PEDROSA NETO, Antônio Henrique e FRANCO JÚNIOR, José Gonçalves. Ob. cit., p. 121. 
O segundo pressuposto, trazido no discutível art. 5. ${ }^{\circ}$, da Lei n. ${ }^{\circ}$ 11.105/2005, determina que sejam utilizadas células-tronco retiradas de embriões congelados há mais de três anos. Tal prática poderá se revelar extremamente danosa se empregada no tratamento de moléstias em pacientes.

Ives Gandra da Silva Martins e Lilian Piñero Eça, ${ }^{12}$ com muita propriedade, valendo-se das lições de Jonathan Knight, Allegrucci, Andrews e Thomson, entre outros, demonstram os graves equívocos em que incorrem os entusiastas da embrioterapia e da utilização de células-tronco retiradas de embriões congelados há muito tempo, para a tentativa de tratamento de moléstias humanas. ${ }^{13}$

$\mathrm{Na}$ Medicina e na Biologia, existe uma considerável corrente de pensamento que desaconselha a utilização de células-tronco embrionárias que não sejam recentes, no tratamento de doenças. ${ }^{14}$ Os embriões congelados há mais de três anos apresentam grande possibilidade de rejeição. “À medida que essas células se diferenciam para substituir as lesadas num tecido degenerado, elas começam a expressar as proteínas responsáveis pela rejeição (Jonathan Knight)." 15 Além dos perigos da rejeição,

${ }^{12}$ MARTINS, Ives Gandra da Silva e EÇA, Lilian Piñero. Verdade sobre células-tronco embrionárias. Jornal Folha de S. Paulo. Opinião. 8.07.2005., p. A3.

${ }^{13}$ EÇA, Lilian Piñero. Opinião. In: Adoção de embriões pode ser alternativa ao seu uso em pesquisas, p._3. Notícias. In: http://www.comciencia.br. Acessado em 06.04.2006.

${ }^{14}$ PERIN, Marcelo. Opinião. In: Adoção de embriões pode ser alternativa ao seu uso em pesquisas, p. 3. Notícias. In: http://www.comciencia.br. Acessado em 06.04.2006.

${ }^{15}$ MARTINS, Ives Gandra da Silva e EÇA, Lilian Piñero. Verdade sobre células-tronco embrionárias. $\mathrm{Ob}$ cit., p. A3. as células-tronco extraídas de embriões congelados, facilmente formam tumores de caráter embrionário, denominados teratomas. (Allegrucci). ${ }^{16}$ É freqüente a ocorrência de metilações no ADN dos embriões congelados, que impedem identificação, "aumentando o risco de silenciarem genes", havendo "total descontrole das células embrionárias, surgindo diferenciações em tecidos distintos nas placas de cultura" não se prestando, pois, para qualquer tipo de pesquisa. ${ }^{17}$ Os pesquisadores Andrews e Thomson, nas conclusões de seus estudos, demonstram que "células-tronco humanas em cultura apresentam anormalidades cromossômicas, à medida que se diferenciam, com risco de se malignizarem."

É de extremada lucidez a reflexão de Ives Gandra da Silva Martins e Lilian Piñero Eça, que não se contagiaram com o superficial e apressado entusiasmo do legislador brasileiro, que ignorando totalmente os incipientes estudos científicos e os perigos da embrioterapia com células-tronco antigas, e os maiores cuidados que os pacientes merecem, propõe mediante legislação apressada, pesquisas e terapia com célulastronco embrionárias velhas e inviáveis, extraídas de embriões congelados de três anos ou mais de criopreservação.

${ }^{16}$ MARTINS, Ives Gandra da Silva e EÇA, Lilian Piñero. Verdade sobre células-tronco embrionárias. Ob. cit., p. A3. Vide: C. Allegrucci, L. Liguori, I. Mezzasoma, A. Minelli. A1 adenosine receptors in human spermatozoa: its role in the fertilization process. Mol. Gen. Metab. Review. 71: 381-386. 2000.

${ }^{17}$ MARTINS, Ives Gandra da Silva e EÇA, Lilian Piñero. Verdade sobre células-tronco embrionárias. Ob. cit., p. A3. 
Todavia, cumpre destacar que a mais festejada terapia que vem se desenvolvendo na atualidade é a baseada em células-tronco adultas sãs, retiradas do próprio paciente, modificadas geneticamente, não devendo ser empregadas células-tronco embrionárias que apresentam inconvenientes, consoante afirmamos acima.

Joel R. Chamberlain, obteve a cura de pacientes portadores de Osteogenesis Imperfecta, uma grave doença que promove desordens ósseas no esqueleto do paciente, a partir do emprego de células-tronco adultas geneticamente modificadas. ${ }^{18}$ Rudolf Jaenisch, demonstra em seus estudos que a célula-tronco adulta pode, através de técnicas apropriadas ser mantida em estado não diferenciado, tal qual uma célula-tronco embrionária, durante determinado lapso de tempo e quando necessário passa-se a deflagrar o processo de diferenciação quando são formados os tecidos desejados. Obtido o tecido necessário para o caso, bastará o implante do mesmo no organismo do paciente. ${ }^{19} 20$

O fato de rejeitarmos as técnicas da embrioterapia, a partir da utilização de células-tronco embrionárias inviáveis e velhas, não significa que sejamos contrários às novas descobertas e às técnicas de cura que veem sendo desenvolvidas pela Medicina, em especial na utilização de células-tronco adultas.

${ }^{18}$ MARTINS, Ives Gandra da Silva e EÇA, Lilian Piñero. Ult. ob. cit., p. A3.

${ }^{19}$ Cell technology. http://www.celltechnology.com. Acessado em 22.09.05.

${ }^{20}$ MARTINS, Ives Gandra da Silva e Eça, Lilian Piñero. Ob. cit., p. A3
Técnicas terapêuticas já desenvolvidas, que estão se desenvolvendo, ou que estão por surgir, demonstram a possibilidade da cura de muitas doenças graves que não sacrificam a vida de outros seres humanos, mesmo que ainda estejam em estado embrionário. Em Cuba, por exemplo, está se desenvolvendo uma nova técnica cirúrgica, no Centro de Pesquisa e Restauração Neurológica CIREN, de Havana, destinada ao tratamento da doença de Parkinson. Trata-se de um tratamento que envolve uma atividade médica multidisciplinar combinando modalidades de terapia neurológica, psiquiátrica, cirúrgica e fisioterápica. O grande relevo é dado pela terapia cirúrgica, através da qual se realiza a cauterização de ambos os lados do subtálamo, que é a parte do cérebro que controla a coordenação da maior parte dos movimentos. Esta cauterização visa queimar alguns neurotransmissores superativos que causam o tremor e a rigidez que caracteriza a doença de Parkinson. Com o auxílio de computador e de programas avançados e mediante a cooperação do próprio paciente, os médicos das especialidades, acima mencionadas, localizam e identificam os pontos exatos do subtálamo que afetam cada parte do corpo do paciente. ${ }^{21}$ Os resultados obtidos são na razão de uma recuperação geral do paciente em $60 \%$, na recuperação dos movimentos do operado em mais de $70 \%$ e na redução em $70 \%$ da terapia medicamentosa, ${ }^{22}$ havendo grande expectativa da evolução para a melhoria dessas técnicas.

${ }^{21}$ SZANIAWSKI, Elimar. O embrião excedente ..., p. $97-98$.

${ }^{22}$ Jornal GAZETA DO POVO, p. 31. 
3 DO PANORAMA DA EMBRIOTERAPIA NO DIREITO COMPARADO

$\mathrm{Na}$ Alemanha, existe uma legislação ampla e minuciosa, o Embryonenschutzgesetz, EschG, (Lei de Proteção dos Embriões), promulgada em 1991, dedicada à proteção da reprodução humana assistida, além de impor limitações em relação à realização de experiências com embriões e de clonagem terapêutica. ${ }^{23}$ A mencionada lei, somente, permite a realização de pesquisas ou diagnóstico de embriões com o objetivo de curar determinadas alterações genéticas para implantar na mãe um embrião saudável e que tenha condições de se desenvolver. Pesquisas com embriões com objetivo de mera investigação científica são vedadas pelo Embryonenschutzgesetz, bem como a clonagem terapêutica. ${ }^{24} 25$

Na Espanha, existe legislação que dispõe sobre a matéria em comento, como a Lei n. ${ }^{\circ} 35$, de 22.11.1988, que regulamenta a reprodução humana assistida. A doação, a pesquisa e a utilização de embriões humanos, suas células e tecidos, para fins terápicos, é regulada pela Lei n. $^{\circ} 42$, de 28.12.1988, a qual autoriza a pesquisa em embriões ditos inviáveis. A grande polêmica, no entanto,

${ }^{23}$ Embryonenschutzgesetz - ESchG ou "Lei de Proteção dos Embriões", promulgada em 13.12.1990 e que passou a vigorar em 01.01.1991.

${ }^{24}$ Embryonenschutzgesetz: vide $\S \S 1 .{ }^{\circ} ; 3^{\circ}$ e $6^{\circ}$.

25 Embora haja proibição expressa da realização de pesquisas com embriões, através do Embryonenschutzgesetz, as instituições de pesquisa, como a Deutschen Forschungsgemeinschaft, (DFG), instituição que promove estudos e pesquisas em embrioterapia, propõe a produção de embriões humanos em escala industrial para o aproveitamento das célulastronco embrionárias na embrioterapia. repousa sobre o verdadeiro significado da expressão, embrião inviável, não havendo um consenso entre médicos, biólogos e juristas sobre o conceito de inviabilidade. Prevalece, na Espanha, o entendimento de que devem ser considerados como embriões inviáveis aqueles que ultrapassaram um limite máximo de tempo criopreservados e que não tenham condições de desenvolver-se em um ser humano saudável.

Na França, a Lei sobre Bioética, de 1994, vedava expressamente pesquisas e experimentos com embriões humanos. No entanto, assim como na Alemanha, há um permissivo legal no sentido de serem realizadas pesquisas ou diagnóstico em embriões, objetivando curar determinadas alterações genéticas para implantar na mãe um embrião saudável e que tenha condições de se desenvolver.

Posteriormente, foi promulgada nova lei, autorizando pesquisas em embriões excedentários, doados pelos genitores para tal finalidade. Vedando, porém, a criação de embriões destinados à pesquisas e que não tenham finalidade procriativa.

Na Inglaterra, o Human Fertilization and Embryology Act, (Lei de Fertilização Humana e Embriologia), de 1990, autoriza a pesquisa com embriões humanos visando descobrir a causa e a cura da esterilidade e das doenças genéticas. A reforma legislativa de 2001 alterou o quadro anterior, permitindo a utilização de células embrionárias na pesquisa de terapias para a cura das doenças consideradas graves. Ultimamente, vem sendo desenvolvida e aplicada a nível experimental, modalidade de terapia embrionária que emprega 
células de embriões humanos e técnicas de clonagem reprodutiva. ${ }^{26}$ Esta modalidade terapêutica utiliza células-tronco a partir de embriões doados por bancos de gametas, sendo empregada no tratamento de doenças degenerativas, como no infarto agudo do miocárdio, na doença de Parkinson e no diabetes mellitus. As lesões irreversíveis que estas moléstias provocam nas células dos órgãos humanos comprometem seriamente a saúde do paciente. Essa terapia pretende possibilitar a substituição das células doentes ou danificadas por células idênticas saudáveis. ${ }^{27}$

Em Portugal, a reprodução humana assistida é regulamentada pela Lei sobre Técnicas de Procriação Assistida, de julho de 1999. No entanto, a proibição da fabricação e utilização de embriões com finalidade de investigação científica vem regulada pelo Decreto n. ${ }^{\circ} 135$, VII, de 1997, que, também, veda a clonagem reprodutiva.

Nos Estados Unidos, as pesquisas sobre a terapia embrionária e medicamentosa é bem desenvolvida, não havendo, na atualidade, vedação legal na utilização de embriões excedentes, para a obtenção das células tipo. ${ }^{28}$

Do exame atento das normas americanas, verifica-se que existem diversas contradições

${ }^{26}$ WILMUT. Avanços na clonagem de células humanas. Highlights do Congresso Europeu de Reprodução Humana, realizado em Bologna, Itália, no mês de junho de 2.000 , p. 3. www.profert.com.br

${ }^{27}$ WILMUT. Ob. cit., p. 3.

${ }^{28} \mathrm{Na}$ década de 1970 , havia sido proibida a utilização de recursos federais para pesquisas em embriões visando a reprodução assistida. Esta proibição, todavia, não impediu a realização de pesquisas com embriões humanos, que passaram a ser feitas em maior volume pelas instituições privadas. legislativas, a exemplo da permissão do uso de células embrionárias provenientes de embriões produzidos especificamente para a produção de células-tronco, desde que as mesmas sejam produzidas em laboratórios sem subvenção federal.

A polêmica sobre o tema é muito grande, havendo posicionamento considerável de segmentos da sociedade que defendem as pesquisas em células-tronco embrionárias e outros que procuram impedir as experimentações com células extraídas de embriões. A maior preocupação daqueles que se mostram contrários à realização de experiências com células-tronco embrionárias, reside na grande possibilidade de envolvimento de empresas com fins econômicos e lucrativos, na obtenção de gametas e embriões, para a produção de células-tronco em nível industrial, que se afastam do cumprimento das normas éticas. ${ }^{29}$

A revista Time, de 25.06.2001, publicou um artigo defendendo a ampla realização de pesquisas com células-tronco embrionárias.

Em sentido oposto, a revista Fertility and Sterility publicou uma interessante matéria sobre o tema, no mês de julho de 2001, na qual faz sérias críticas às pesquisas com células embrionárias, extraídas de embriões produzidos sem finalidade reprodutiva. ${ }^{30}$ O citado artigo mostra a forte reação dos "grupos de defesa da vida" americanos, condenando estas espécies de pesquisas,

\footnotetext{
${ }^{29}$ OTCHET, Amy. Es ética la clonation de embriones ? El Correo de la UNESCO. Caderno Libertades. Edição de abril de 2001.

${ }^{30}$ LANZENDORF, Susan. Use of human gametes obtained from anonymous donors for the production of human embryonic stem cell lines. Revista Fertility and Sterility. Vol. 76. Issue 1, p. 132-137.
} 
classificando-as como uma modalidade de aborto. ${ }^{31}$

No entretanto, o Instituto Jones de Medicina Reprodutiva, do Estado da Virgínia, vem continuamente utilizando embriões concebidos in vitro, mediante emprego de gametas de doadores, especialmente destinados para a realização de pesquisas científicas. ${ }^{32}$ A técnica empregada pela equipe médica do Instituto Jones de Medicina Reprodutiva, chefiada pela Dr. ${ }^{a}$ Susan Lanzendorf, utiliza o embrião que atingiu o estado de blastócito, decompondo-o, a fim de obter cepas de células embrionárias que serão injetadas no corpo do paciente na tentativa da obtenção da cura de sua moléstia. ${ }^{33}$

Conclui-se que, embora haja forte reação de muitos segmentos da sociedade européia e americana como um todo, no sentido de vedar o emprego de células-tronco, extraídas de embriões humanos, com finalidade de tratamento da saúde humana, bem como pesquisas e experimentos com células embrionárias, os laboratórios e as instituições de pesquisas vêm atuando amplamente no sentido de descobrir a cura de doenças por meio de células-tronco embrionárias.

\section{DA SITUAÇÃO JURÍDICA DO EMBRIÃO EXCEDENTE}

Aprendemos que a personalidade do ser humano tem início a partir de seu nascimento com vida, pondo, porém, a lei a salvo, desde

\footnotetext{
31 Vide resumo da matéria em http://www.ncbi. nlm.gov/

32 JORNAL GAZETA DO POVO. Curitiba. Edição de Quinta-feira, 12 de julho de 2001, p. 31.

${ }^{33}$ GOLDIM, José Roberto. In: http://www.bioetica. ufrgs.br/celtron.htm. Acessado em 16.02.2006.
}

a concepção, os direitos do nascituro. Esta lição tem sua origem, respectivamente, nos arts. $2 .^{\circ}$ e $4 .^{\circ}$, dos Códigos Civis brasileiros de 2002 e de 1916, respectivamente, ${ }^{34}$ inspirados nos modelos europeus que, por sua vez, filiaram-se à doutrina desenvolvida pelo direito romano, que vislumbrava o embrião e o feto, como sendo parte das vísceras da mãe, destituído de autonomia genético-biológica.

Assim, vem-se sustentando há séculos que a personalidade civil do homem começa do nascimento com vida, não bastando, contudo, o mero fato nascimento para a aquisição da personalidade, sendo necessário, também, que o nascituro nasça vivo, ou, simplesmente, que tenha respirado. A respiração do recém-nascido estabelece sua existência jurídica no universo extrauterino e lhe outorga a personalidade.

O direito tradicional, como é sabido, embora não reconheça ao embrião nem ao nascituro a personalidade natural, outorga ao último, uma proteção especial, uma vez que se trata de um indivíduo em vias de existir e que está para nascer. Desta maneira, as codificações civis asseguram, desde a concepção, direitos ao nascituro, equiparando-o à pessoa, na defesa de seus interesses. Perdura no Direito moderno a regra infans conceptus pro habatur, quoties de commodis ejus agitur. Sob o enfoque tradicional, o nascituro devidamente protegido, pode ser reconhecido pelo pai, bem como está apto a adquirir bens por

${ }^{34} \mathrm{CC} / 2002$. Art. 2. : "A personalidade civil da pessoa começa do nascimento com vida; mas a lei põe a salvo, desde a concepção, os direitos do nascituro."

CC/1916. Art. 4. ". "A personalidade civil do homem começa do nascimento com vida; mas a lei põe a salvo desde a concepção os direitos do nascituro." 
sucessão hereditária, embora não seja portador de personalidade. ${ }^{35}$ Se nascer morto, nada receberá, passando a herança a outros herdeiros que estejam vivos. Esta é a regra clássica que, ainda, perdura nos dias atuais.

No entanto, a evolução das ciências naturais no limiar do séc. XX, como a Biologia e a Medicina, nos trouxe um conhecimento mais profundo do ser humano em seu aspecto biológico. A ciência comprova que o ser humano, enquanto inserido no ventre materno, não se constitui em meras vísceras da mãe e sim constitui-se em um ser humano em desenvolvimento, possuidor de autonomia genético-biológica.

Essa percepção veio a ocupar seu devido lugar nas ciências, vindo a ser entendida por todas as áreas do conhecimento humano, inclusive pelo jurista, que passou, paulatinamente, a abandonar a concepção romana da aquisição da personalidade, apartando-se da idéia de um inseparável vínculo biológico entre a mãe e o filho até seu nascimento, ante a autonomia biológica deste, desde a concepção. Assim, surgiu um novo entendimento, no sentido de reconhecer que o concebido é um ser humano que irá se desenvolver, possuindo, contudo, uma identidade genética própria, diversa da de seus genitores, não se constituindo mais em um aglomerado de células germinativas e sim em um novo ser humano que possui características biogenéticas próprias e exclusivas. A partir dessa constatação biológica, desenvolveu-se a teoria concepcionista da aquisição da personalidade, que reconhece a personalidade humana aos

${ }^{35}$ GOMES, Orlando. Introdução ao Direito Civil, p.144. indivíduos que ainda não nasceram, sendo, conseqüentemente, o embrião e o nascituro portadores de personalidade a partir de sua individualidade e de sua identidade genética própria, independentemente de sua vinculação com as entranhas da mãe. Conseqüentemente, os seguidores da teoria biológica, a concepcionista, admitem a existência de personalidade nos indivíduos humanos, mesmo os ainda não nascidos, a qual se inicia e existe desde o momento de sua concepção, ${ }^{36}$ embora existam divergências quanto ao exato momento em que o indivíduo adquire a personalidade, predominando a idéia de que a personalidade humana é adquirida após a fase da nidação.

Embora a Biologia e a Medicina tenham demonstrado que o embrião, desde o momento da concepção, é um novo indivíduo, portador de autonomia genéticobiológica, permanece a resistência por parte de alguns, em recepcionar a teoria concepcionista da aquisição da personalidade humana, continuando a defender a teoria natalista. Tal recusa em aceitar que o embrião, desde a concepção, deve ser reconhecido como sendo uma pessoa, portadora de personalidade, sendo um sujeito de direitos, reside, basicamente, na grande dificuldade de o direito tentar explicar por que o feto que possuiria personalidade desde a concepção, constituindo-se em um sujeito de direitos e que viesse a nascer morto, não conservaria sua personalidade nem os direitos adquiridos a partir desta. O natimorto, por exemplo, não adquire nem transmite eventuais direitos

${ }^{36}$ SZANIAWSKI,Elimar.Direitos depersonalidade..., p. 67. AMARAL, Francisco. Ob. cit., p. 211. LEITE, Eduardo de Oliveira. O direito do embrião humano: mito ou realidade. Revista de Direito Civil, Imobiliário, Agrário e Empresarial. N. ${ }^{\circ} 78$, p. 22 e ss.. 
sucessórios aos herdeiros. Por essa razão, a fim de a doutrina poder contornar com maior facilidade os problemas sobre os eventuais direitos do natimorto, preferem os autores conservadores manter-se alinhados com a doutrina clássica, reconhecendo a aquisição da personalidade, somente, aos indivíduos que tenham nascido vivos, ou que, somente, tenham respirado. Para estes, aqueles que não chegaram a respirar, não são considerados pessoas nem sujeitos de direito.

\section{DA SITUAÇÃO JURÍDICA DO EMBRIÃO NO DIREITO BRASILEIRO}

Consoante acima se falou, o direito brasileiro aparentemente ter-se-ia filiado à teoria natalista ou genético-desenvolvimentista, segundo se infere da exegese dos arts. $4{ }^{\circ} \mathrm{e}$ 2. ${ }^{\circ}$, dos Códigos Civis de 1916 e de 2.002, respectivamente, que estabelecem o momento para a aquisição da personalidade do ser humano, o seu nascimento com vida. No entanto, este entendimento não se coaduna com o sistema do Código Civil, uma vez que da análise atenta de todo o Código, quer o de 2.002, quer o de 1916, verifica-se que a teoria da aquisição da personalidade do ser humano recepcionada pelo legislador brasileiro é a teoria concepcionista, consoante será demonstrado a seguir, uma vez que o Código Civil outorga direitos ao embrião a partir de sua concepção.

\subsection{Da aquisição da personalidade humana no código civil de 1916}

$\mathrm{O}$ art. 4. $^{\circ}$, do Código Civil derrogado, isoladamente analisado, conduziu a doutrina brasileira dominante a afirmar que o ser humano concebido mas não nascido, não seria possuidor de personalidade, pois o ser humano só a adquiriria após o nascimento e desde que fosse com vida.

Embora o Código Civil brasileiro de 1916, consoante já afirmamos, determine no art. $4 .^{\circ}$, que a personalidade civil da pessoa teria início a partir do seu nascimento com vida, o próprio Código outorgava ao concebido, desde o momento de sua concepção, uma série de direitos subjetivos expressos em diversos artigos na Parte Geral e Especial, verificando-se que a noção de ser o embrião um ser humano portador de personalidade é antiga no direito brasileiro.

Uma codificação legislativa não deve ser examinada analisando-se artigo por artigo isoladamente. Um código é um sistema jurídico completo e complexo, devendo, portanto, ser analisado por inteiro, sistematicamente, verificando-se a ideologia e a principiologia que o informa. $\mathrm{O}$ exame de alguns dispositivos legais do antigo Código demonstra que o legislador de 1916 absorveu a idéia de ser o embrião um sujeito de direitos e, conseqüentemente, ser considerado uma pessoa.

O art. 353, do Código Civil de 1916, autorizava a legitimação de filho apenas concebido; no § único, do art. 357, possibilitava o reconhecimento de filho, antes mesmo de nascer; no art. 462, dispunha sobre a curatela do nascituro e no art. 1.718, reconhecia a capacidade jurídica do nascituro para adquirir bens e direitos por testamento.

Do exposto, conclui-se que a legislação civil brasileira outorgava ao nascituro, desde sua concepção, extensa capacidade jurídica. Por essas razões, interpretava a doutrina menos conservadora o art. $4^{\circ}$, do Código Civil, de maneira sistemática, em conjunto 
com os demais dispositivos legais da Parte Especial, acima mencionados, reconhecendo ao embrião e ao nascituro a personalidade, considerando-os sujeitos de direitos.

\subsection{Da aquisição da personalidade humana no código civil de 2002}

O Código Civil de 2.002, um código bastante conservador para o terceiro milênio, não se afastou da disciplina trazida no Código Civil de 1916. Repete, praticamente, no art. $2 .^{\circ}$, o disposto no art. $4 .^{\circ}$, do Código Civil de 1916. Da mesma maneira que o Código Civil derrogado, a legislação civil codificada de 2.002, traz na Parte Especial a idéia de ser o embrião um sujeito de direitos e, consequentemente, ser uma pessoa, portadora de personalidade jurídica. Permite o Código Civil em vigor, no $\S$ único, do art. 1.609, o reconhecimento de filho, antes mesmo de nascer; no art. 1.779, dispõe sobre a curatela do nascituro e no art. 1.798 legitima como sucessoras as pessoas já concebidas no momento da abertura da sucessão. O Código Civil de 2002 atribui a personalidade ao concebido, denominando-o expressamente de "pessoa", no art. 1.798. ${ }^{37}$ Deve, portanto, ser abandonada definitivamente a antiga concepção sobre a aquisição da personalidade natural, filiada à teoria genético-desenvolvimentista ou natalista, que retira a personalidade do nascituro, atribuindo ao mesmo a caracterização de "coisa" protegida pela lei,

37 “Art. 1.798. Legitimam-se a suceder as pessoas nascidas ou já concebidas no momento da abertura da sucessão." (Grifos nossos). não lhe conferindo, porém, nenhum direito subjetivo. ${ }^{38}$ A mencionada teoria compara a proteção do nascituro, dada pela lei civil, à proteção de um objeto inanimado.

\subsubsection{Da aquisição da personalidade humana no projeto de lei . $^{\circ}$ 6.960/2002 - Projeto de reforma do código civil de 2002}

O Deputado Federal Ricardo Fiúza, autor do Projeto de Lei n. ${ }^{\circ}$ 6.960/2002, propõe uma ampla e necessária reforma do Código Civil de 2002, cuja proposta, em relação ao art. 2. , do Código Civil, consiste na inserção da figura do embrião ao lado da do nascituro, passando ambos a merecer tutela jurídica como seres humanos em desenvolvimento, portadores de personalidade. Passará o dispositivo proposto a ter a seguinte redação:
“Art. 2. ${ }^{\circ}$ A personalidade civil da pessoa começa do nascimento com vida; mas a lei põe a salvo, desde a concepção, os direitos do embrião e os do nascituro."

Lamentavelmente é extremamente tímida e modesta a proposta de reforma do art. $2 .^{\circ}$, do Código Civil, uma vez que o citado diploma legal continuará atrelado às duas teorias que

${ }^{38} \mathrm{O}$ Direito Penal sempre reconheceu ser o embrião e o nascituro pessoas, sujeitos de direitos, sendo sua vida e seu direito de nascer devidamente protegidos, constituindo-se a interrupção da vida, antes do nascimento, no delito de aborto. Muitos códigos penais, a exemplo do Código Penal Suíço, inscrevem o aborto como um crime contra a vida, ao lado do infanticídio e do homicídio, ou seja, constitui-se em um delito contra a vida de um ser humano que possui o direito de nascer. O Código Penal brasileiro, acertadamente, dispõem sobre o crime de aborto nos arts. 124 a 128, incluindo-o como delito contra a vida. 
tratam da aquisição da personalidade do ser humano, discrepantes e contraditórias, não resolvendo o problema criado pelo legislador civil, a reboque das arcaicas e vetustas tradições romanas e divorciado da realidade científica do mundo contemporâneo.

Diante da disparidade encontrada no Código Civil que, em sua Parte Geral, adotaria a teoria genético-desenvolvimentista da aquisição da personalidade e na Parte Especial, adota a teoria concepcionista, reconhecendo a efetiva personalidade ao concebido, bem como ser o mesmo um sujeito de direitos, todavia sem direito à percepção do direito de herança aos natimortos, a doutrina passou a elaborar algumas teorias a fim de tentar explicar a razão de o embrião que não lograsse nascer, embora sendo uma pessoa e sujeito de direitos, não herdar bens do de cujus parente. Estas teorias serão, a seguir, analisadas.

\subsection{Da natureza jurídica do embrião no direito brasileiro}

A doutrina brasileira dominante não considera o embrião e o nascituro portadores de personalidade, justificando seu pensamento na exegese literal do art. 2. ${ }^{\circ}$ do Código Civil.

Tendo, porém, a Biologia e a Medicina demonstrado que o embrião, desde o momento da concepção, é um novo indivíduo, portador de autonomia genético-biológica, sendo, conseqüentemente, uma pessoa, surgem diversas teorias, a partir da teoria concepcionista, que procuram explicar o motivo pelo qual o natimorto não adquire nem transmite eventuais direitos sucessórios aos herdeiros.

\subsubsection{Da doutrina pré-codificadora}

A doutrina civilista brasileira do Séc. XIX, inspirada nas Ordenações Filipinas, ${ }^{39}$ sustentava que a aquisição da personalidade do ser humano iniciava-se a partir da concepção.

Teixeira de Freitas, em sua Consolidação das Lei Civis, afirmava que "todos os entes que apresentarem sinais característicos da humanidade, sem distinção de qualidades ou acidentes, são pessoas de existência visível." Teixeira de Freitas denominava estes indivíduos de "pessoas por nascer." Segundo o renomado jurista, aquelas que embora "não sendo ainda nascidas, acham-se, porém, já no ventre materno," ${ }^{40}$ são pessoas, possuem personalidade e capacidade de direito, outorgando-lhes a lei a necessária representação. Possuidores de personalidade e de capacidade, as pessoas por nascer estão aptas a adquirir direitos. Todavia, a aquisição destes direitos, para Teixeira de Freitas, dá-se mediante condição resolutiva de não nascimento com vida. ${ }^{41}$

No tocante à sucessão, sustentava o autor que para as pessoas que se desenvolvem no ventre materno, a lei garante-lhes os direitos sucessórios para o tempo de seu nascimento. ${ }^{42}$

${ }^{39}$ As Ordenações Filipinas determinavam que a personalidade do ser humano iniciava-se a partir da concepção. Ord.. 3, 18, § 7; 4. 82, § 5. .

${ }^{40}$ TEIXEIRADE FREITAS, Augusto. Consolidação das Leis Civis: arts. 1. ${ }^{\circ}$; 35; 53; 221 e 226.

${ }^{41}$ OLIVEIRA, José Lamartine Corrêa de. Teoria das Pessoas no Esboço de Teixeira de Freitas. Superação e Permanência. In: Augusto Teixeira de Freitas e il diritto latinoamericano. A cura di Schipani, Sandro, p. 350 e 366 .

${ }^{42}$ TEIXEIRADE FREITAS, Augusto. Consolidação ...: arts. $1 .{ }^{\text {o }} ; 35 ; 53 ; 54 ; 221$ e 226 
Possuem aptidão não só para serem herdeiros, mas, também, para serem donatários. No entanto, possuía o nascituro uma limitação qualitativa em sua capacidade.

Segundo percepção atenta de Corrêa de Oliveira, os que estão para nascer, só adquiririam direitos sob condição resolutiva de um eventual não nascimento com vida. Percebe-se da análise do sistema de Direito Civil de Teixeira de Freitas, que este separava, com perfeita distinção, os conceitos de personalidade e de capacidade e o concebido era considerado pessoa e portador de capacidade civil.

Carlos de Carvalho ${ }^{43}$ e Clóvis Beviláqua, ${ }^{44}$ acompanhavam o pensamento de Teixeira de Freitas, ensinando que a personalidade da pessoa se inicia com a concepção, sob a condição de nascer viva.

Embora Clóvis Beviláqua se aprumasse com os doutrinadores que defendiam que a personalidade civil do ser humano tem início com sua concepção, traduzindo seu pensamento no art. 3. ${ }^{\circ}$, do Projeto do Código Civil, o legislador de 1916 alterou a redação originária do Projeto, afirmando no art. $4^{\circ}$, que a personalidade civil do homem começa do nascimento com vida, garantindo, todavia, desde a concepção, os direitos do nascituro.

Consoante se verifica desta exposição, a doutrina brasileira pré-codificadora do séc. XIX considerava o concebido uma pessoa, portadora de personalidade e de capacidade civil, possuindo, inclusive, capacidade para adquirir direitos patrimoniais mediante condição resolutiva de não nascimento com vida.

${ }^{43}$ CARVALHO, Carlos de. Direito Civil Recompilado, art. 74 .

${ }^{44}$ ClÓvis BEVILAQUA. Projeto do Código Civil, art. 3. .

\subsubsection{Da doutrina contemporânea}

A maior parte da doutrina da atualidade, porém, continua mantendo seu pensamento firmado na antiga exegese do art. $4 .^{\circ}$, do Código Civil de 1916, dispositivo repetido no art. 2. ${ }^{\circ}$, do Código Civil de 2002, defendendo a aquisição da personalidade do ser humano, somente, a partir do nascimento com vida.

Adoutrina brasileira menos conservadora, ${ }^{45}$ admite ser o nascituro, bem como o embrião, pessoas, possuidoras de personalidade, não só sob o ponto de vista doutrinário, mas, igualmente, sob a ótica da análise sistemática do Código Civil, consoante afirmamos no item 4.2, supra, que conduz o estudioso à concluir que o legislador filiou-se à teoria concepcionista.

No entanto, existe um grande problema que ainda não foi decisivamente solucionado. Nenhuma dúvida paira quanto à personalidade do embrião que está se desenvolvendo no ventre de uma mulher. Este é considerado pessoa, possuidor de personalidade natural e de capacidade jurídica.

A grande polêmica reside na diversidade de pensamento no tocante ao embrião desenvolvido in vitro e que esteja depositado em um banco de armazenamento de gametas a espera de seu destino. Em relação ao embrião in vitro, não existe uma uniformidade de pensamento entre os adeptos da teoria concepcionista da aquisição da personalidade do ser humano.

${ }^{45}$ AMARAL, Francisco. Ob. cit., p. 211. DINIZ. Maria Helena. Ob. cit., p. 113. LEITE, Eduardo de Oliveira. $O$ direito do embrião humano ..., p. 22. MARTINS, Yves Gandra da Silva e EÇA, Lilian Piñero. Verdade sobre células-tronco embrionárias, p. A3. MEIRELLES, Jussara Maria Leal de. Ob. cit. p., 22. OLIVEIRA, José Lamartine Corrêa de. Teoria das Pessoas..., p. 385. SZANIAWSKI, Elimar. O embrião excedente ..., p. 89. 
Para grande parte dos seguidores desta corrente, somente o embrião que estiver se desenvolvendo no ventre de uma mulher será considerado uma pessoa, possuidora de personalidade. Os demais embriões que não estão ligados à mãe e que ainda estejam vivendo em uma proveta não são, para esta corrente de pensamento, considerados pessoas, conseqüentemente, estariam destituídas de personalidade. Esta fato justificaria o descarte de embriões in vitro ou sua utilização em experimentos e na embrioterapia.

De outro lado, estão os juristas que defendem a igualdade material dos embriões humanos, não admitindo distinção entre um embrião que esteja se desenvolvendo no ventre materno daquele que está em uma proveta ou em um banco de embriões. Ambos são seres humanos em desenvolvimento, foram concebidos, podendo vir a nascer e, por esta razão, possuem personalidade natural. ${ }^{46}$

$\mathrm{Na}$ tentativa de contornar a problemática dos fetos que são abortados naturalmente, dos indivíduos natimortos e dos embriões in vitro, que se constituem em seres humanos que não nasceram nem vivenciaram a vida extra-uterina, alguns autores, adeptos da teoria concepcionista, entendem em dividir a personalidade natural em duas categorias, criando uma verdadeira dicotonomia da personalidade humana. Neste sentido, o indivíduo ao ser concebido adquiriria uma parte da personalidade, denominada de

${ }^{46}$ AMARAL, Francisco. Ob. cit., p. 211. DINIZ. Maria Helena. Ob. cit., p. 113. LEITE, Eduardo de Oliveira. $O$ direito do embrião humano ..., p. 22. MARTINS, Yves Gandra da Silva e EÇA, Lilian Piñero. Ob. cit. p. A3. MEIRELLES, Jussara Maria Leal de. Ob. cit. p., 22. SZANIAWSKI, Elimar. O embrião excedente ..., ps. 89-90. personalidade formal e, após o término da gestação, o indivíduo nascendo com vida, adquiriria a outra parte da personalidade, a personalidade material. $\mathrm{O}$ fato, nascimento com vida, é que outorgaria ao indivíduo uma personalidade ampla e completa, a personalidade material.

Aos primeiros, portadores de uma personalidade meramente formal, seriam reconhecidos, somente, direitos de personalidade. Aos possuidores de uma personalidade material, por nascerem com vida, além dos direitos inerentes à personalidade já adquiridos com a concepção, seriam titulares de outros direitos, além dos de personalidade, como os direitos patrimoniais, que estariam, segundo este pensar, em estado potencial. ${ }^{47}$ Em conclusão, segundo esta corrente, pode-se afirmar que tanto o embrião como o nascituro, que estejam se desenvolvendo no ventre materno, bem como o embrião in vitro, por possuírem todos carga genética diferenciada, adquiriram com a concepção a personalidade formal, sendo apenas titulares de direitos de personalidade. E os fetos que viessem a nascer com vida receberiam, a partir deste momento, a personalidade material e, junto com esta, a capacidade de direito.

Não podemos concordar com esta bipartição da personalidade humana em personalidade formal e personalidade material por absoluta falta de lógica e de coerência. Esta teoria, embora aparentemente procure solucionar o problema das pessoas natimortas e dos embriões não utilizados pelos genitores na reprodução assistida, acaba

${ }^{47}$ DINIZ. Maria Helena. O Estado Atual do Biodireito, p. 114. 
por colocar o simples vagido da criança como o elemento fundamental da atribuição da efetiva personalidade, o que se constitui em um critério totalmente casuístico, divorciado de qualquer elemento científico.

De outro lado, a divisão da personalidade humana em formal e material é totalmente inaplicável no Direito brasileiro, uma vez que as codificações civis do Brasil, desde sua inauguração em 1. ${ }^{\circ}$ de janeiro de 1917 , outorgam diversas categorias de direito ao concebido, inclusive direitos patrimoniais, a exemplo do Código Civil de 2.002, o qual, no art. 1.798, legitima como sucessoras as pessoas já concebidas no momento da abertura da sucessão, possuindo estas o direito de herdar bens de natureza patrimonial. ${ }^{48} 49$

\footnotetext{
${ }^{48}$ SZANIAWSKI,Elimar. Direitos depersonalidade ..., p. 65 .

${ }^{49}$ SZANIAWSKI, Elimar. $O$ embrião excedente ..., p. 91. SOUSA, R. V. A. Capelo de. O Direito Geral de Personalidade, p. 158. Neste trabalho de nossa autoria, resumimos os passos trilhados pelo embrião na conquista de sua autonomia em relação ao corpo da mãe, o qual percorreu o seguinte caminho: "o primeiro passo que trouxe uma certa independência ao feto, em relação à sua mãe, foi o desenvolvimento das encubadoras que albergam os nascidos prematuramente, permitindo que estes terminem seu desenvolvimento intra-uterino fora do corpo da mãe, constituindo-se a encubadora em um verdadeiro útero artificial. $\mathrm{O}$ advento das técnicas de fertilização assistida inauguraram a independência do filho em relação ao corpo de sua mãe, mediante a fertilização in vitro, técnica através da qual se concebe um ser humano fora do corpo humano e sem a intervenção de relações sexuais. O útero de substituição, que consiste em um útero de terceira pessoa, no qual uma criança se desenvolve, diverso do de sua mãe biológica, consolidou a idéia de que o concebido possui existência distinta da de sua mãe biológica. Finalmente, a possibilidade de manter um embrião vivo, indefinidamente, fora do corpo humano, através das técnicas da criopreservação, reiteram a afirmação acima, de que o concebido possui existência distinta da de sua mãe biológica, não se podendo admitir, na atualidade, a idéia de ser o embrião um ente humano que possui existência intimamente ligada e dependente de sua mãe" biológica.
}

Deve ser, ainda, considerado que existe a possibilidade de na sucessão testamentária, serem sucessores do de cujus os filhos de pessoas indicadas pelo testador, mesmo os ainda não concebidos, consoante previsão expressa do inciso I, do art. 1799, do Código Civil, condicionando, porém, esta possibilidade ao fato de, por ocasião da abertura da sucessão, tenha o herdeiro nascido com vida, nos termos do $\S 3 .^{\circ}$, do art. 1800. Caso contrário, não vindo a existir o herdeiro esperado, decorridos dois anos após a abertura da sucessão, os bens reservados, salvo disposição em contrário do testador, serão outorgados aos herdeiros legítimos. Esta possibilidade de o testador indicar como sucessor um indivíduo que ainda não existe, com a finalidade de sucedê-lo, em caso de falecimento, é admitida em diversas legislações, a exemplo o Código Civil italiano e do Código Civil português, respectivamente na alínea 3 , do art. 462 e alínea 2 , letra a , do art. $2.033 .^{50}$

Embora alguns defendam a equivocada idéia de que existiria uma bipartição da personalidade humana, consoante assinalamos acima, predomina entre os concepcionistas a noção de que a personalidade natural do ser humano surge a partir da concepção, todavia sujeita à condição resolutiva de o embrião ou feto não vir a nascer com vida.

Os positivistas, ao contrário, sustentam que a atribuição da personalidade ao embrião e ao nascituro, constitui-se em uma questão meramente de técnica jurídica. Se a lei outorga a personalidade ao ser humano, será a própria lei quem dirá o momento em que a pessoa adquire esta personalidade.

${ }^{50}$ SZANIAWSKI, Elimar.Direitos de personalidade ..., p. 68-69. 
Nesse sentido, demonstra Francisco Amaral,,${ }^{51}$ com muita serenidade, o equívoco daqueles que atrelam a gênese da personalidade da pessoa humana ao seu nascimento com vida. Para o autor, a atribuição da personalidade ao embrião e ao nascituro, constitui-se em uma questão de mera política legislativa tendo em vista que legislações há que reconhecem a personalidade a estes e outras que não a admitem.

O sistema do Direito Civil brasileiro como um todo revela que os codificadores do direito civil filiaram-se à teoria concepcionista, segundo a qual o concebido, o embrião e o nascituro, são, desde a fecundação, um ser humano individualizado, distinto da mãe, possuidor de autonomia genéticobiológica, ${ }^{52}$ tratando-se de um ser humano em desenvolvimento, sendo, por isso, uma pessoa e sujeito de direitos..$^{53}$

Por essas razões, não encontramos dificuldades em afirmar que o embrião e o nascituro, desde a concepção, constituemse em seres dotados de uma estrutura e de uma dinâmica humana autônomas, de uma identidade genética própria e exclusiva, constituindo-se em uma spes personae. ${ }^{54}$

${ }^{51}$ AMARAL, Francisco. Ob. cit., ps. 211-212.

52 LEITE, Eduardo de Oliveira. Procriações Artificiais e o Direito, p. 385. A teoria concepcionista além de conceber "o embrião, desde a fecundação, algo distinto de sua mãe, com uma autonomia genéticobiológica, a qual não permite estabelecer nenhuma mudança essencial em sua natureza até a idade adulta, salvo os óbvios atributos de tamanho e função."

${ }^{53}$ AMARAL, Francisco. Ob. cit., p. 211. LEITE, Eduardo de Oliveira. Ob. cit., p. 385. SOUSA, R. V. A. Capelo de. Ob. cit., p. 158. SZANIAWSKI, Elimar. O embrião excedente ..., p. 90.

${ }^{54}$ SZANIAWSKI,Elimar. Direitos de personalidade..., p. 66.
Possui, pois, o embrião, consoante está sendo demonstrado, uma única e exclusiva personalidade natural. ${ }^{55}$

Conseqüentemente, garantindo a Constituição da República no caput do art. $5 .^{\circ}$, o direito à vida, combinado com a garantia da dignidade da pessoa humana, expressamente prevista no inciso III, do art. $1 .^{\circ}$, da lei Maior e pondo a lei civil a salvo,

55 A jurisprudência brasileira expressamente reconhece que o embrião e o nascituro, que estão se desenvolvendo no ventre materno, são portadores de personalidade, consoante pode ser constatado nos dois arestos que seguem:

"DANO MORAL-ACIDENTEDE TRÂNSITO-ATO ILÍCITO - MORTE de NASCITURO - INDENIZAÇÃO devida

Para a caracterização de caso fortuito, capaz de elidir o dever de indenizar o dano causado, é necessário que tal circunstância fique absolutamente comprovada nos autos. 2. De conseguinte, não tendo a apelante se desincumbindo a contento do ônus de comprovar a ocorrência de caso fortuito, consistente no furto do veículo causador do dano, a sua responsabilidade pelo evento danoso é inafastável. 3. Considerando-se que o nascituro é pessoa desde o momento da concepção $\left(\mathrm{CC}\right.$, art. $\left.4^{\circ}\right)$, conclui-se que é perfeitamente cabível indenização, a título de danos morais, em razão da sua morte prematura, provocada por ato ilícito, consistente em lesões corporais sofridas pela mulher grávida. (TA/PR - Ap. Cív. n. 0095081-2 - Com. de Curitiba Ac. 7326 - unân. - 2a. Câm. Cív. - Rel: Juiz Rosene Arão de Cristo Pereira - j. em 16.10.96 - Fonte: DJPR, 08.11.96, p. 57. In BONIJURIS Jurisprudência Cd-Rom - 29292.“

"NASCITURO - MORTE - INDENIZAÇÃO por DANO MORAL - Fixação - Aplicabilidade do ART. 1537/CC, II

Em indenização por dano moral decorrente da morte de feto, admissível a aplicação do art. 1.537, II, do CC, em analogia aos casos de homicídio praticado contra menor impúbere, considerando-se razoável o critério que estabelece o quantum indenizatório em número de salários mínimos correspondentes aos meses que mediariam entre o evento danoso e a data em que o nascituro completaria vinte e cinco anos de idade. (TA/ MG - Ap. Cív. n. 190.169-3 - Comarca de Governador Valadares - Ac. unân. - 3a. Câm. Cív. - Rel: Juiz Tenisson Fernandes - Fonte: DJMG II, 03.08.95, p. 12. In BONIJURIS Jurisprudência - Cd-Rom - 24414)." 
desde a concepção, os direitos do nascituro, constitui-se o ser humano, que está sendo gerado, em um sujeito de direitos, merecedor de tutela jurídica, não podendo ser afastada a idéia de que o concebido, como sujeito de direitos, é necessariamente portador de personalidade natural única independentemente, esteja o mesmo no interior do ventre de sua mãe, no ventre de outra mulher, a mãe substituta ou, mesmo, se desenvolvendo em um tubo de ensaio. $\mathrm{O}$ concebido, qualquer que seja o local em que se desenvolva ou esteja sendo preservado é sempre uma pessoa e portador de personalidade natural. ${ }^{56}$

\subsection{Do projeto de lei n. $^{\circ}$ 90/1999}

Segundo concluímos acima, embora a corrente de pensadores que se opõe à destruição de embriões humanos para sua utilização na embrioterapia, na fabricação de medicamentos e de cosméticos, venha se fortalecendo dia a dia, não somente no Brasil mas, também, em outros países, o legislativo brasileiro mantém-se fiel à teoria genéticodesenvolvimentista, apresentando diversos projetos de lei e votando leis que autorizam experiências com embriões humanos que, fatalmente, serão mortos. ${ }^{57}$

O Projeto de lei mais amplo e detalhado que procura regulamentar a reprodução humana assistida no Brasil, PL n. ${ }^{\text {o 90/1999, }}$

\footnotetext{
${ }^{56}$ Discordamos da expressão, "personalidade jurídica" da pessoa natural ou física, que está ultimamente em voga na doutrina brasileira. Segundo pensamos, toda pessoa natural, possui personalidade natural. "Personalidade jurídica," possuem, somente, as pessoas jurídicas.

${ }^{57}$ SZANIAWSKI, Elimar. Direitos de personalidade ..., p. $153 ; 469 ; 480 ; 556$.
}

que ainda tramita nas casas do Congresso Nacional é de autoria do Senador Lúcio Alcântara. O Projeto de Lei n. ${ }^{\circ}$ 90/1999, através de seu art. $9 .{ }^{\circ},{ }^{58}$ procura trazer soluções ao destino dos embriões humanos gerados em proveta e criopreservados em hospitais e clínicas de fertilização humana e que não são aproveitados pelos genitores para a gestação de filhos. ${ }^{59} \mathrm{Em}$ decorrência do problema dos embriões excedentes que se encontram criopreservados na clínicas de fertilização humana, o autor do Projeto de

${ }^{58}$ Deve ser observado que a numeração dos parágrafos do art. 9..$^{\circ}$ está incorreta. Faltam os $\S \S 3 .^{\circ} \mathrm{e}$ $6 .^{\circ}$ e existem dois $\S \S 4 .^{\circ}$, na publicação do texto original. Mantivemos a numeração originária do texto de lei.

${ }^{59}$ Projeto de lei n. ${ }^{\circ}$ 90/1999 :

"Art. $9^{\circ}$. Os estabelecimentos que praticam a RAficam autorizados a preservar gametas e embriões humanos, doados ou depositados apenas para armazenamento, pelos métodos permitidos em regulamento.

$\S 1^{\circ}$ Não se aplicam aos embriões originados in vitro, antes de sua introdução no aparelho reprodutor da mulher receptora, os direitos assegurados ao nascituro na forma da lei.

$\S 2^{\circ} \mathrm{O}$ tempo máximo de preservação de gametas e embriões será definido em regulamento.

$\S 4^{\circ} \mathrm{O}$ número total de embriões produzidos em laboratório durante a fecundação in vitro será comunicado aos usuários para que se decida quantos embriões serão transferidos a fresco, devendo o restante ser preservado, salvo disposição em contrário dos próprios usuários, que poderão optar pelo descarte, a doação para terceiros ou a doação para pesquisa.

$\S 5^{\circ}$ Os gametas e embriões depositados apenas para armazenamento só poderão ser entregues ao indivíduo ou casal depositante, sendo que, neste último caso, conjuntamente aos dois membros do casal que autorizou seu armazenamento.

$\S 4^{\circ}$ É obrigatório o descarte de gametas e embriões:

I - doados há mais de dois anos;

II - sempre que for solicitado pelos doadores;

III - sempre que estiver determinado no documento de consentimento informado;

IV - nos casos conhecidos de falecimento de doadores ou depositantes;

$\mathrm{V}$ - no caso de falecimento de pelo menos uma das pessoas que originaram embriões preservados." 
Lei opta, segundo suas próprias declarações na Justificação do Projeto, pelo simples descarte dos embriões excedentes, pela razão de, segundo seu juízo, implicar "menores riscos do que a doação para terceiros ou para pesquisas." Para o senador Lúcio Alcântara, o descarte dos embriões excedentes estará salvaguardando a proteção da criança que se desenvolveu, fortalecendo, segundo sua ótica, o princípio da paternidade responsável. Embora o Senador Lúcio Alcântara tenha dado preferência pelo descarte dos embriões excedentes, segundo pode ser vislumbrado na Justificação do Projeto de Lei n. ${ }^{\circ}$ 90/1999, este Projeto de lei acaba por adotar, no art. $9 .^{\circ}$, a possibilidade de doação de embrião excedente para terceiros e na doação para pesquisas científicas, além do descarte proposto.

Segundo propõe expressamente o Projeto de Lei em comento, não se aplicam aos embriões fertilizados in vitro, antes de sua introdução no ventre da mulher receptora, os direitos assegurados ao nascituro no art. 2. ${ }^{\circ}$, do Código Civil.$^{60}$ Desse modo, verificase que Lúcio Alcântara e seu Projeto de lei excluem do embrião, que não esteja se desenvolvendo no ventre de uma mulher, a personalidade natural. Para o Projeto de lei, o embrião desenvolvido in vitro constituirse-ia, tão-somente, em uma res, objeto de direito, vislumbrando o embrião in vitro um mero material genético descartável. ${ }^{61}$

Sustentamos, anteriormente, demonstrando que o embrião inserido no interior do ventre de mulher ou dentro de uma proveta é,

${ }^{60}$ Cf. determina o art. $9 .^{\circ}, \S 1 .^{\circ}$, do Projeto de lei n. ${ }^{\text {900/1999. }}$

${ }^{61}$ Art. 9. ${ }^{\circ}, \S 4 .^{\text {o }},\left(3 .^{\circ}\right)$, do Projeto de lei n..$^{\text {9 }}$ 90/1999. igualmente, uma pessoa, no sentido jurídico do termo, possuidor de identidade genética própria, de dignidade e do direito à vida. ${ }^{62}$

\section{DO DIREITO À VIDA E DE NASCER COMO UM DIREITO LIMITADO}

A Lei.$^{\circ}{ }^{11.105 / 05}$, ao autorizar, para fins de pesquisa e terapia, a utilização de células-tronco embrionárias, obtidas de embriões humanos por fertilização in vitro que sejam inviáveis ou congelados há três anos ou mais, na data da publicação da mencionada Lei, ou que, já congelados na data de sua publicação completarem três anos, abriu nova discussão, extremamente polêmica, sobre a relativização do direito à vida no ordenamento jurídico brasileiro.

Verificando-se nosso sistema jurídico como um todo, temos que a Constituição do Brasil garante, expressamente, no caput do art. 5. ${ }^{\circ}$, a inviolabilidade do direito à vida, como um direito fundamental. Ao lado deste direito fundamental, encontramos outro, no mesmo dispositivo constitucional, que tutela a igualdade de todos, perante a lei, sem distinção de qualquer natureza. Para emoldurar o quadro dos direitos fundamentais aplicáveis à tutela dos embriões humanos, invocamos o art. 227, da Constituição, que trata da proteção especial à criança. Apesar de um embrião não poder ser classificado como criança, a Constituição de 1988, como um sistema legal unitário, que traz os fundamentos e os princípios que norteiam a República Federativa do Brasil, garante a mesma proteção especial àqueles que deverão nascer, inclusive em relação aos embriões.

\footnotetext{
${ }^{62}$ SZANIAWSKI,Elimar. Direitos depersonalidade ...,
} p. 70 . 
Os doadores de gametas, ao doar seu material genético às clínicas de fertilização ou aos bancos de gametas, estão transmitindo contratualmente a propriedade desse material. Os usuários da reprodução assistida, na fertilização homóloga, transferem a posse de seu material genético às entidades que desenvolvem a reprodução assistida que se tornam depositárias dos gametas. $\mathrm{Na}$ transferência das células germinativas, por meio de doação, ou mesmo se tratando, somente, de depósito, estão envolvidos sêmen e óvulos, que são, somente, células reprodutoras humanas. Por enquanto, ainda não existe um ser humano em desenvolvimento, nem um concepto, muito menos, um embrião.

A partir da fecundação, seja mediante inseminação artificial no útero materno, seja in vitro, o material genético empregado na fertilização deixa de ser um mero conjunto de células germinativas, transformando-se em um novo ser, um ser humano vivo que não pode ser objeto de direito de propriedade. Os embriões são seres humanos em desenvolvimento que surgem como resultado da fecundação das células sexuais masculina e feminina, não sendo mais células germinativas dos genitores. As de células germinativas diferem do embrião, não se confundindo com o mesmo. Desse modo, deveria ser vedada a livre disposição dos embriões pelos próprios pais biológicos. A proposta contida no Projeto de Lei n. ${ }^{\circ}$ 90/99, se convertida em lei, outorgará aos pais o direito de livre disposição sobre o destino de vida alheia, que atentaria contra o direito de personalidade do embrião, que é titular do direito à vida e de nascer.

No entanto, o texto constitucional ao promover o direito à vida não define, expressamente, se este direito se apresenta como uma categoria jurídica absoluta ou relativa. $\mathrm{Ou}$, em outras palavras, será que o direito à vida compreenderia relativização mediante imposição de normas que limitassem sua extensão e seus efeitos mediante exceções?

A alínea a, do inciso XLVII, do art. . $^{\circ}$, da Constituição, revela que o próprio constituinte inseriu limitações ao direito absoluto à vida, autorizando a aplicação da pena de morte nos casos em que houver guerra declarada.

A Convenção Americana sobre Direitos Humanos, em relação à qual o Brasil é signatário, declara em seu art. $4 .^{\circ}$, que toda pessoa tem o direito inalienável de ter respeitada sua vida, não podendo este direito ser suspenso por motivo algum. Os Estados americanos tentam restringir ao máximo a aplicação da pena de morte, objetivando tutelar a vida humana em sua extensão máxima. Os Estados-Parte da Convenção Americana sobre Direitos Humanos, mediante a Convenção Internacional sobre Direitos Humanos, realizada em 8.06.1990, durante a XXa Assembléia-Geral da Organização dos Estados Americanos, em Assunção, Paraguai, consolidaram a prática da não-aplicação da pena de morte no continente americano, firmando o Protocolo Adicional à Convenção Americana sobre Direitos Humanos Referente à Abolição da Pena de Morte..$^{63} \mathrm{O}$ referido

${ }^{63} \mathrm{O}$ Protocolo Adicional à Convenção Americana sobre Direitos Humanos, referente à Abolição da Pena de Morte, foi adotado em Assunção, em 8 de junho de 1990 e assinado pelo Brasil em 7 de junho de 1994, passando a vigorar a nível internacional em 28 de agosto de 1991. Este Protocolo foi submetido e aprovado pelo Congresso Nacional através do Decreto Legislativo n. ${ }^{\circ}$ 56, de 19 de abril de 1995. o Governo brasileiro depositou o Instrumento de Ratificação do referido Protocolo, em 13 de agosto de 1996, com a aposição de reserva, nos 
Protocolo internacional dispõe em seu art. 1. ${ }^{\circ}$ que "os Estados-Parte neste Protocolo não aplicarão em seu território a pena de morte a nenhuma pessoa submetida à sua jurisdição. Esta regra internacional, que procura extinguir a pena de morte nos países americanos, é regulamentada no Brasil

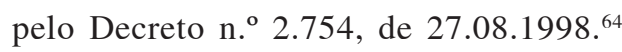
A legislação brasileira veda a prática da pena de morte, estando assegurado o direito à vida e de a mesma não ser suprimida por meio de execução da pessoa pelo Estado. Permanece, todavia, a possibilidade de aplicar-se a pena de morte, excepcionalmente, nos casos em que houver guerra declarada. Esta exceção constitui-se em uma limitação legislativa ao direito absoluto à vida.

Verifica-se que a Constituição do Brasil vislumbra o direito à vida de maneira relativa, admitindo a supressão da vida humana excepcionalmente, nos casos em que houver guerra declarada. Diante desse quadro, cabe indagar:

Poderia, então, utilizar-se o legislador desta mesma restrição ao direito absoluto à

termos do Artigo II, no qual é assegurado aos Estados Partes o direito de aplicar a pena de morte em tempo de guerra, de acordo com o Direito Internacional, por delitos sumamente graves de caráter militar, passando o mesmo a vigorar, para o Brasil, em 13 de agosto de 1996.

${ }^{64}$ Soa o Decreto n. ${ }^{\circ} 2.754$, de 27/08/1998:

Art. $1^{\circ}$. O Protocolo Adicional à Convenção Americana sobre Direitos Humanos Referente à Abolição da Pena de Morte, adotado em Assunção, em 8 de junho de 1990, e assinado pelo Brasil em 7 de junho de 1994, apenso por cópia ao presente Decreto, deverá ser executado e cumprido tão inteiramente como nele se contém.

Art. $2^{\circ}$. Este Decreto entra em vigor na data de sua publicação.

Brasília, em 27 de agosto de 1998; $177^{\circ}$ da Independência e $110^{\circ}$ da República.

Fernando Henrique Cardoso - Luiz Felipe Lampreia. vida, para limitar o direito à vida e de nascer dos embriões in vitro não aproveitados na fertilização?

Sob esse aspecto, o legislador infraconstitucional estaria igualmente autorizado a, em casos especiais, impor outros limites ao direito absoluto à vida, como, por exemplo, estabelecendo a possibilidade de sacrificar embriões humanos, cujas célulastronco seriam destinadas para a cura de moléstias, por meio da embrioterapia.

Mas qual seria o fundamento jurídico que autorizaria o legislador a impor limites ao direito à vida, permitindo a morte de embriões excedentários para a utilização das célulastronco na embrioterapia ?

Tal problema merece ser analisado sob dois enfoques. $\mathrm{O}$ primeiro, no tocante à personalidade do embrião. $\mathrm{O}$ segundo, sob o aspecto da colisão e da ponderação de dois direitos fundamentais, o direito à vida e de nascer do embrião e o direito à vida e à saúde do enfermo, cuja cura poderá ocorrer por meio de terapia com células-tronco embrionárias.

Para analisarmos o primeiro enfoque, deveremos retornar ao Capítulo 5.3.2, supra, que trata do momento da aquisição da personalidade do ser humano.

Consoante foi acima afirmado, a atribuição da personalidade ao embrião constitui-se em uma questão de simples técnica jurídica. ${ }^{65}$ Filiadas à Teoria da Realidade Técnica, as codificações civis do Brasil cuidaram da personalidade, tanto da personalidade humana como a das pessoas jurídicas, como um produto da técnica jurídica. Desse modo, outorgando a lei a personalidade ao ser humano, será a própria lei que determinará

\footnotetext{
${ }^{65}$ AMARAL, Francisco. Ob. cit., p. 211-212.
} 
o momento em que a pessoa adquire esta personalidade e quais seriam os limites. A atribuição da personalidade ao embrião e ao nascituro, constitui-se, pois, em uma questão de mera política legislativa. ${ }^{66}$

Nesse sentido, verifica-se pela Teoria da Realidade Técnica, que procura explicar, embora sob um ponto de vista extremamente positivista, o momento da aquisição da personalidade do ser humano, a possibilidade de o legislador impor limites ao direito absoluto à vida e de nascer, mormente tratando-se de embriões inviáveis ou criopreservados há mais de três anos.

O segundo enfoque, consoante anunciamos acima, parte da análise da colisão e da ponderação dos direitos fundamentais à vida e de nascer do embrião e o direito à vida e à saúde da pessoa enferma, cuja cura poderá se dar mediante o emprego da embrioterapia.

Para verificarmos qual o direito fundamental que esteja colidindo com outro, deva prevalecer na espécie, aplica-se o critério da proporcionalidade, ponderando-se os bens e os direitos postos em causa. Pesando-se os bens e interesses do embrião excedente, inviável e criopreservado há mais de três anos, que não possui condições de se desenvolver de maneira saudável e o direito do enfermo que nasceu e vivenciou parte da vida e que, podendo obter a cura da moléstia que o acomete, certamente o fiel da balança penderá para o lado que defende a cura de graves enfermidades, cujos pacientes, praticamente desenganados, teriam uma possibilidade real de manter a vida e a saúde.

Finalizando, concluímos, discordando dos argumentos expendidos pelo Sr. Procurador Geral da República, Cláudio Fonteles, em

${ }^{66}$ AMARAL, Francisco. idem. p. 211-212. sua Ação Direta de Inconstitucionalidade junto ao $\mathrm{STF}^{67}$ por meio da qual, argüi a inconstitucionalidade do art. $5^{\circ}$, da Lei n. ${ }^{\circ}$ $11.105 / 05$. Para nós, diante dos fundamentos expostos neste trabalho, o referido art. $5 .^{\circ}$, da Lei de Biosegurança, é constitucional, uma vez que a Constituição brasileira relativiza o direito à vida e de nascer, não vedando ao legislador infraconstitucional a imposição de limites ao direito à vida e de nascer dos embriões excedentários in vitro.

Lamentavelmente, nossa Suprema Corte, até o presente momento, ainda não julgou a Ação Direta de Inconstitucionalidade, intentada pelo Procurador Geral da República, cuja decisão certamente será no sentido da improcedência do pedido formulado pelo requerente.

Todavia, cumpre-nos lembrar que não nos parece que a utilização de células-tronco, extraídas de embriões excedentários inviáveis ou "velhos", crioarmazenados há mais de três anos, seja a melhor modalidade terapêutica para as diversas moléstias que acometem a humanidade. Sob este aspecto, filiamo-nos aos pensadores que refutam o art. $5^{\circ}$, da Lei $n .^{\circ} 11.105 / 2.005$, por entenderem que a utilização de células-tronco, extraídas de embriões congelados há mais de três anos, ou inviáveis, por apresentarem grande possibilidade de rejeição, desenvolvimento de câncer e degeneração, são extremamente danosas no tratamento de moléstias em pacientes, prestando-se, somente, para eventuais pesquisas ou para a satisfação da curiosidade científica.

${ }^{67}$ STF. Ação Direta de Inconstitucionalidade do art. 5. ${ }^{\circ}$, da Lei n. ${ }^{\circ} 11.105 / 2.005$. ADI n. ${ }^{\circ} 3.510 / 05$. Relator: Min. Carlos Britto. Requerente Procurador Geral da República. Requeridos: Presidente da República e Congresso Nacional. 


\section{DAS CONCLUSÕES}

1. Areprodução humana assistidaé conceituada como sendo um procedimento médico destinado a possibilitar aos casais que não podem obter a fecundação da mulher por meios naturais lograrem a fecundação por técnicas artificiais, objetivando o nascimento de filhos.

2. Existem milhões de embriões humanos congelados e depositados em clínicas de fertilização humana que não serão utilizados para a reprodução humana que constituem os denominados embriões excedentes.

3. A embrioterapia consiste na parte da Medicina que se dedica ao estudo e pesquisas objetivando a busca de uma modalidade de tratamento de moléstias graves; a fabricação de medicamentos capazes de curar diversas doenças, em especial, as hematológicas, as oncológicas e as onco-hematológicas, nas quais são utilizadas células-tronco embrionárias.

4. A extração de células-tronco embrionárias resulta na morte do embrião. Por estas razões, existe uma considerável corrente de pensadores que se opõem ao emprego de células-tronco extraídas de embriões no tratamento das moléstias humanas, sob alegação de que a morte do embrião constitui-se na morte de um ser humano em desenvolvimento, que possui o direito à vida e de nascer.

5. O art. 5. $^{\circ}$, da Lei n. $.^{\circ} 11.105 / 05$, autoriza no Brasil a pesquisa, a terapia e a utilização de células-tronco embrionárias obtidas de embriões humanos produzidos por fertilização in vitro e não utilizados no respectivo procedimento, desde que sejam embriões inviáveis; ou embriões congelados há três anos ou mais, na data da publicação da referida Lei, ou que, já congelados na data da sua publicação depois de completarem três anos, contados a partir da data de congelamento.

6. Na Medicina e na Biologia, encontramos uma corrente de pensamento que sustenta que os embriões congelados não se prestam para fornecer células-tronco destinadas ao tratamento de doenças. Os embriões congelados há mais de três anos podem apresentar possibilidade de rejeição, do desenvolvimento de teratomas e de degeneração, o que constitui um grande perigo ao paciente.

7. Existem outras modalidades terapêuticas que possuem eficiência semelhante à embrioterapia, que consistem na terapia de Restauração Neurológica; na utilização de células-tronco retiradas da placenta e de células-tronco adultas, extraídas do próprio paciente, que não destróem o embrião humano.

8. A codificação civil brasileira contempla na Parte Especial, a idéia de ser o embrião um sujeito de direitos e, conseqüentemente, ser uma pessoa, portadora de personalidade natural, adotando, pois, a teoria concepcionista da aquisição da personalidade.

9. Para grande parte dos autores que se filiam à teoria concepcionista, haveria igualdade jurídica entre o embrião que se desenvolve no ventre materno e o embrião in vitro e qualquer mácula à sua saúde e à sua integridade psicofísica, constitui-se em atentado contra seu direito de personalidade. 
10. AConstituição brasileira impõe limitações ao direito absoluto à vida, autorizando a aplicação da pena de morte nos casos em que houver guerra declarada, relativizando, desta maneira, o direito à vida, que deixa de ser absoluto.

11. A Constituição não veda ao legislador infraconstitucional de, em casos especiais, a imposição de outros limites ao direito absoluto à vida, como, por exemplo, estabelecendo a possibilidade de sacrificar embriões humanos, cujas células-tronco seriam destinadas à cura de moléstias, através da embrioterapia.

12. A Teoria da Realidade Técnica atribui à técnica jurídica o momento da fixação da aquisição da personalidade do ser humano, possibilitando, desta maneira, ao legislador impor limites ao direito absoluto à vida e de nascer, mormente tratando-se de embriões inviáveis ou criopreservados há três anos ou mais.

13. O art. 5. ${ }^{\circ}$, da Lei n. ${ }^{\circ} 11.105 / 05$, é constitucional, diante da concepção relativa do direito à vida e de nascer, adotada pela Constituição, não havendo vedação ao legislador infraconstitucional de impor limites ao direito à vida e de nascer. $\mathrm{O}$ fato de ser discutível o aproveitamento de células-tronco embrionárias inviáveis ou antigas, principalmente pelo fato de poderem apresentar degeneração e não se apresentarem adequadas ao emprego na embrioterapia, não conduz à inconstitucionalidade do mencionado dispositivo legal, como equivocadamente entendem alguns pensadores.

\section{REFERENCIAS}

ALLEGRUCCI, L. Liguori, I. Mezzasoma, A. Minelli. Al adenosine receptors in human spermatozoa: its role in the fertilization process. Mol. Gen. Metab. Review. 71: 381-386. 2000.

AMARAL, Francisco. Direito Civil. Introdução. 2.ed. Rio de Janeiro: Renovar.

Cell Technology. In: www.cell technology.com. Acessado em 16.02.2006.

DINIZ. Maria Helena. O Estado Atual do Biodireito. São Paulo: Saraiva, 2001.

EÇA, Lilian Piñero. Opinião. In: Adoção de embriões pode ser alternativa ao seu uso em pesquisas. Notícias in http://www.comciencia.br. Acessado em 06.04.2006.

Embryonenschutzgesetz - EschG. ("Lei de Proteção dos Embriões"), promulgada em 13.12.1990.

FERREIRA, Aurélio Buarque de Hollanda. Pequeno Dicionário Brasileiro da Língua Portuguesa. 10.ed. Rio de Janeiro : Civilização Brasileira.

FREITAS, Augusto Teixeira de. Consolidação das Leis Civis. Coleção: história do direito brasileiro. Direito Civil 1. Senado Federal. Conselho Editorial. 2003.

GOLDIM, José Roberto. In: http://www. bioetica.ufrgs.br/. Acessado em 16.02.2006.

GOMES, Orlando. Introdução ao Direito Civil. Atualização e notas de Humberto Theodoro Júnior. 12.ed. Rio de Janeiro: Forense, 1997.

JORNAL GAZETA DO POVO. Edição de Quinta-feira, 12 de julho de 2001.

LANZENDORF, Susan. Use of human gametes obtained from anonymous donors for the production of human embryonic stem cell lines. Revista Fertility and Sterility. Vol. 76. Issue 1.

LEITE, Eduardo de Oliveira. O direito do embrião humano: mito ou realidade. Revista de Direito Civil, Imobiliário, Agrário e Empresarial. N.78. São Paulo. RT.

LEITE, Eduardo de Oliveira. Procriações Artificiais e o Direito. São Paulo: RT, 1995. 
MARTINS, Ives Gandra da Silva e Eça, Lilian Piñero. Verdade sobre células-tronco embrionárias. Jornal Folha de S. Paulo. Opinião. Edição de 08.07.2005.

MEIRELLES, Jussara Maria Leal de. A Vida humana Embrionária e sua Proteção Jurídica. Rio de Janeiro : Renovar, 2000.

OLIVEIRA, José Lamartine Corrêa de. Teoria das Pessoas no Esboço de Teixeira de Freitas. Superação e Permanência. In: Augusto Teixeira de Freitas e il diritto latinoamericano. A cura di Schipani, Sandro. Padova : Cedam, 1988.

OTCHET, Amy. Es ética la clonation de embriones? El Correo de la UNESCO. Caderno Libertades. Edição de abril de 2001.

PEDROSA Neto, Antônio Henrique e FRANCO JÚNIOR, José Gonçalves. Reprodução Assistida. Iniciação à Bioética. Coordenação de Sérgio Ibiapina Ferreira Costa. Gabriel Oselka e Volnei Garrafa. Brasília. CFM. 1998.
PERIN, Marcelo. Opinião. In: Adoção de embriões pode ser alternativa ao seu uso em pesquisas. Notícias. In http://www.comciencia. br. Acessado em 06.04.2006.

Revista Fertility and Sterility. v.76, jul.2001.

SOUSA, R. V. A. Capelo de. O Direito Geral de Personalidade. Coimbra: Ed. Coimbra, 1995.

SZANIAWSKI, Elimar. O embrião excedente $\mathrm{O}$ primado do direito à vida e de nascer. Revista Trimestral de Direito Civil. Rio de Janeiro. Padma. v. 8. 83/107. an.2001.

SZANIAWSKI, Elimar. Direitos de personalidade e sua tutela. 2.ed. São Paulo: Revista dos Tribunais, 2005.

WILMUT. Avanços na clonagem de células humanas. In: Highlights do Congresso Europeu de Reprodução Humana, realizado em Bologna, Itália, no mês de junho de 2000. In http.www. profert.com.br. Acessado em março de 2001. 